\title{
INVESTIGATIONS ON SERUM LIPID COMPONENTS AND SERUM VITAMIN E IN IRON DEFICIENCY ANEMIA
}

\author{
Takaaki FuJII and Hiroshi SHIMIzU ${ }^{1}$ \\ Department of Central Clinical Laboratory of Saiseikai \\ Utsunomiya Hospital, Utsunomiya 320 \\ (Received October 18, 1972)
}

\begin{abstract}
Investigations were carried out on serum lipid components and serum vitamin $\mathrm{E}$ in 54 cases of iron deficiency anemia during adolescence, with the following results: Serum levels of total lipids, free fatty acids, and phospholipids in cases of iron deficiency anemia were not different from those of the controls. Although the average value of serum total cholesterol levels in the cases of iron deficiency anemia was not different from that of the controls, the percentage of subjects who showed low serum total cholesterol levels was greater in cases of iron deficiency anemia than in controls. The average values of serum triglyceride, serum beta-lipoprotein, or serum vitamin $\mathrm{E}$ were significantly lower than those of the controls, and the percentage of subjects who showed low serum levels of triglyceride, beta-lipoprotein, or vitamin $\mathrm{E}$ was greater in cases of iron deficiency anemia than in the controls. No significant correlation was noted between serum levels of vitamin $\mathrm{E}$ and total cholesterol. However, a moderate correlation was noted between serum levels of vitamin $\mathrm{E}$ and triglyceride, and a direct correlation was noted between serum levels of vitamin $\mathrm{E}$ and beta-lipoprotein.
\end{abstract}

Vitamin $\mathrm{E}$ is a compound with antioxidant properties capable of protecting membrane lipids from oxidative degradation(l). A reduction in serum vitamin $\mathrm{E}$ concentration is associated with increased susceptibility of red blood cells to hemolysis on exposure to $\mathrm{H}_{2} \mathrm{O}_{2}$ in vitro(2-5). MELHORN and Gross(6) reported that abnormally elevated $\mathrm{H}_{2} \mathrm{O}_{2}$ hemolysis values were observed in cases of severe iron deficiency anemia in children. As reported by the authors previously, abnormally elevated $\mathrm{H}_{2} \mathrm{O}_{2}$ hemolysis values and moderate reduction in serum vitamin $\mathrm{E}$ concentration were also observed in adult patients with iron deficiency anemia(7). The real cause of decreased serum vitamin $E$ level in iron deficiency anemia is not known. However, as vitamin $\mathrm{E}$ is fat soluble, this paper investigates

\footnotetext{
1 藤井高明, 清水 宏
} 
the status of serum lipid components and serum vitamin $\mathrm{E}$ in iron deficiency anemia in an attempt to clarify the cause of vitamin E deficiency in this anemia.

\section{MATERIALS AND METHODS}

Cases of iron deficiency anemia among Japanese ranging in age from 15 to 17 were studied. In these cases, the range of hemoglobin level was 4.2 to $10.9 \mathrm{~g} /$ $100 \mathrm{ml}$, serum iron was 40.0 to $75.0 \mu \mathrm{g} / 100 \mathrm{ml}$, and total iron binding capacity was 390.5 to $492.0 \mu \mathrm{g} / 100 \mathrm{ml}$. In this study, the subjects selected were all cases of idiopathic hypochromic anemia. Patients with anemia due to gastrointestinal or genital hemorrhage and parasitic infections were excluded. The nutritional status of all subjects was almost normal except for anemia. The serum levels of total lipids (sulfo-phospho-vanillin method), free fatty acids (Itaya-Ui method), phospholipids (Hoeflmayer-Fried method), total cholesterol(Zurkowski method), triglyceride(acetic aceton method), beta-lipoprotein(Hoeflmayer-Fried method), and total tocopherol(Rindi method) were determined in 54 cases ( 3 males, 51 females) who were made to fast before iron therapy. The same examination was carried out for 28 healthy female adolescents, as controls, ranging in age from 15 to 17 with hemoglobin levels above $12.0 \mathrm{~g} / 100 \mathrm{ml}$.

\section{RESULTS}

Average values and distributions of serum total lipid levels, free fatty acid levels, and phospholipid levels in cases of iron deficiency anemia were not significantly different from those of controls. The average value of serum total cholesterol levels in cases of iron deficiency anemia was not significantly different from that of controls either. However, the percentage of subjects who showed serum total cholesterol levels below $149.0 \mathrm{mg} / 100 \mathrm{ml}$ was greater in cases of iron deficiency anemia $(27.8 \%)$ than in controls $(3.5 \%)$. The average value of serum triglyceride levels in cases of iron deficiency anemia $(67.6 \pm 28 \mathrm{mg} / 100 \mathrm{ml})$ was lower than that of the controls $(89.1 \pm 21 \mathrm{mg} / 100 \mathrm{ml})$, and the percentage of subjects who showed serum triglyceride levels below $49.0 \mathrm{mg} / 100 \mathrm{ml}$ was greater in cases of iron deficiency anemia $(20.4 \%)$ than the controls $(0 \%)$ (statistically significant). The average value of serum beta-lipoprotein levels in cases of iron deficiency anemia $(299.4 \pm 61 \mathrm{mg} / 100 \mathrm{ml})$ was lower than that of the controls $(389.0 \pm 51 \mathrm{mg} / 100 \mathrm{ml})$, and the percentage of subjects who showed serum betalipoprotein levels below $249.0 \mathrm{mg} / 100 \mathrm{ml}$ was greater in cases of iron deficiency anemia $(31.5 \%)$ than in the controls $(0 \%)$ (statistically significant). The average value of serum vitamin $\mathrm{E}$ levels in cases of iron deficiency anemia $(1.07 \pm 0.26 \mathrm{mg}$ / $100 \mathrm{ml})$ was significantly lower than that of the controls $(1.24 \pm 0.10 \mathrm{mg} / 100 \mathrm{ml})$, and the percentage of subjects who showed serum vitamin E levels below $0.79 \mathrm{mg} /$ $100 \mathrm{ml}$ was greater in cases of iron deficiency anemia $(9.5 \%)$ than the controls 
Table 1. Levels of serum lipid components and serum vitamin $\mathrm{E}$ in iron deficiency anemia.

\begin{tabular}{|c|c|c|c|c|}
\hline & & $\begin{array}{l}\text { Controls } \\
\text { (28 cases) }\end{array}$ & $\begin{array}{c}\text { Iron } \\
\text { deficiency } \\
\text { anemia } \\
\text { (54 cases) }\end{array}$ & $P$ \\
\hline $\begin{array}{l}\text { Total lipids } \\
(\mathrm{mg} / 100 \mathrm{ml})\end{array}$ & $\begin{array}{c}\text { average }(\mathrm{M} \pm \mathrm{S} . \mathrm{D} .) \\
\text { below } 399 \\
400-600 \\
\text { above } 601\end{array}$ & $\begin{array}{c}480 \pm 68 \\
17.8 \% \\
78.6 \% \\
3.5 \%\end{array}$ & $\begin{array}{c}485 \pm 82 \\
7.4 \% \\
87.0 \% \\
5.5 \%\end{array}$ & $>0.05$ \\
\hline $\begin{array}{l}\text { Free fatty acids } \\
(\mathrm{mEq} / 100 \mathrm{ml})\end{array}$ & $\begin{array}{c}\text { average }(\mathrm{M} \pm \mathrm{S} . \mathrm{D} .) \\
\text { below } 0.29 \\
0.30-0.50 \\
\text { above } 0.51\end{array}$ & $\begin{array}{c}0.42 \pm 0.14 \\
7.1 \% \\
82.1 \% \\
10.7 \%\end{array}$ & $\begin{array}{c}0.39 \pm 0.13 \\
9.3 \% \\
77.8 \% \\
12.9 \%\end{array}$ & $>0.05$ \\
\hline $\begin{array}{l}\text { Phospholipids } \\
(\mathrm{mg} / 100 \mathrm{ml})\end{array}$ & 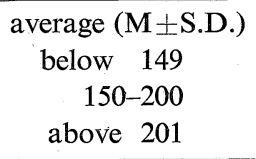 & $\begin{array}{c}167.3 \pm 28 \\
3.5 \% \\
96.4 \% \\
0 \%\end{array}$ & $\begin{array}{c}161.2 \pm 31 \\
7.4 \% \\
87.0 \% \\
5.5 \% \\
\end{array}$ & $>0.05$ \\
\hline $\begin{array}{l}\text { Total cholesterol } \\
(\mathrm{mg} / 100 \mathrm{ml})\end{array}$ & $\begin{array}{c}\text { average (M士S.D.) } \\
\text { below } 149 \\
\begin{array}{c}150-200 \\
\text { above } 201\end{array}\end{array}$ & $\begin{array}{c}180.6 \pm 29 \\
3.5 \% \\
82.1 \% \\
14.2 \%\end{array}$ & $\begin{array}{c}173.9 \pm 34 \\
27.8 \% \\
62.9 \% \\
9.2 \%\end{array}$ & $>0.05$ \\
\hline $\begin{array}{l}\text { Triglycerides } \\
(\mathrm{mg} / 100 \mathrm{ml})\end{array}$ & 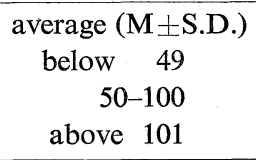 & $\begin{array}{l}89.1 \pm 21 \\
0 \% \\
85.7 \% \\
14.3 \%\end{array}$ & $\begin{array}{l}67.6 \pm 28 \\
20.4 \% \\
74.0 \% \\
5.5 \% \\
\end{array}$ & $<0.01$ \\
\hline $\begin{array}{l}\text { Beta-lipoprotein } \\
(\mathrm{mg} / 100 \mathrm{ml})\end{array}$ & $\begin{array}{c}\text { average (M } \pm \text { S.D.) } \\
\text { below } 249 \\
250-500 \\
\text { above } 501\end{array}$ & $\begin{array}{c}389.0 \pm 51 \\
0 \% \\
96.4 \% \\
3.5 \%\end{array}$ & $\begin{array}{c}299.4 \pm 61 \\
31.5 \% \\
66.6 \% \\
1.8 \%\end{array}$ & $<0.01$ \\
\hline $\begin{array}{l}\text { Vitamin E } \\
(\mathrm{mg} / 100 \mathrm{ml})\end{array}$ & $\begin{array}{c}\text { average }(\mathrm{M} \pm \mathrm{S} . \mathrm{D} .) \\
\text { below } 0.79 \\
0.80-1.09 \\
\text { above } 1.10\end{array}$ & $\begin{array}{c}1.24 \pm 0.10 \\
0 \% \\
14.2 \% \\
85.7 \%\end{array}$ & $\begin{array}{c}1.07 \pm 0.26 \\
9.5 \% \\
55.6 \% \\
35.1 \%\end{array}$ & $<0.01$ \\
\hline
\end{tabular}

$(0 \%)$ (Table 1). No statistically significant correlation was noted between serum vitamin E levels and serum total cholesterol levels $(r=0.425)$. A moderate correlation was noted between serum vitamin $\mathrm{E}$ levels and serum triglyceride levels $(r=0.641)$. A direct correlation was noted between serum vitamin E levels and serum beta-lipoprotein levels $(r=0.857)$ (Fig. 1).

\section{DISCUSSION}

Low serum cholesterol levels have been observed in cases of chlorosis( 8$)$ and chronic anemia with splenomegaly such as splenic anemia, Banti's syndrome, and 
congenital microspherocytosis(9). REFKIND(9) reported that serum total cholesterol levels below $150 \mathrm{mg} / 100 \mathrm{ml}$ were observed in 13 out of 26 cases of chronic anemia due to various etiologies and that phospholipid levels measured in 10 subjects were also considerably reduced, but that serum triglyceride levels were

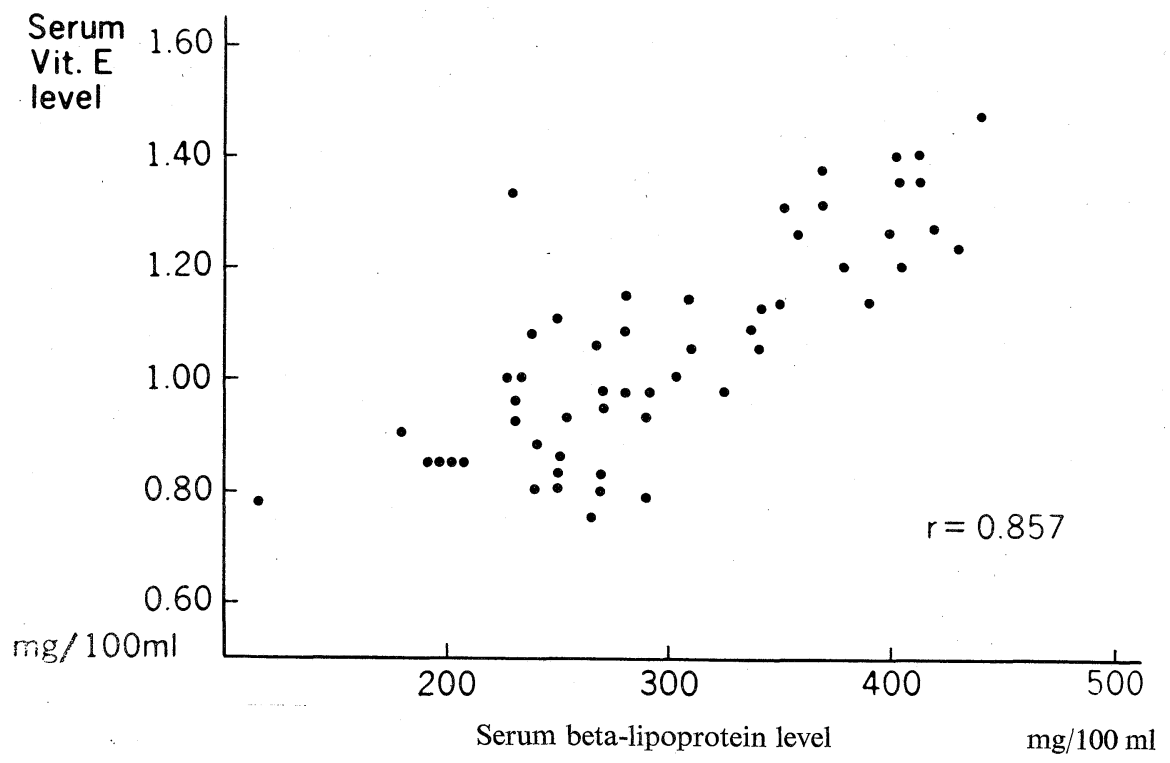

Fig. 1. Relation of serum vitamin E level to serum beta-lipoprotein level in iron deficiency anemia.

normal in 6 subjects. In this study, although serum levels of total lipids, free fatty acids, and phospholipids were normal, low serum levels of total cholesterol, triglyceride, beta-lipoprotein, or vitamin $\mathrm{E}$ were demonstrated in some cases of iron deficiency anemia.

As reported previously $(10,11)$, the low linoleic acid content in serum unsaturated fatty acid composition in neutral lipids was demonstrated in cases of iron deficiency anemia before treatment. In addition, although the spleen was not palpable in any of 96 cases of iron deficiency anemia during adolescence, fairly large latent splenomegaly was demonstrated by roentogenographic examinations in $27.1 \%$ of the cases $(12)$. It has been reported that lipids such as cholesterol and phospholipids are important constituents of the red blood cell membrane $(13,14)$, and such lipids in blood serum are constantly being incorporated into the red blood cell membrane(15-17). In addition, SILBER et al.(18) reported that vitamin $\mathrm{E}$ in red blood cells is localized in the red blood cell membrane and that rapid exchange of vitamin $\mathrm{E}$ takes place between the red blood cell and blood serum.

It is well known that vitamin $\mathrm{E}$ is a strong antioxidant and prevents cell damage by lipoperoxidation of unsaturated fatty acids. It has been reported by 
many investigators that in a vitamin $\mathrm{E}$ deficient state, the red blood cells become fragile and are easily hemolyzed by $\mathrm{H}_{2} \mathrm{O}_{2}(1-5)$. DoDGE(19) reported that red blood cells from patients with abetalipoproteinemia (acanthocytosis) showed marked sensivity to $\mathrm{H}_{2} \mathrm{O}_{2}$ and a decrease in polyunsaturated fatty acids in red blood cell membranes. MELHORN and Gross(6) reported that an abnormal elevation of $\mathrm{H}_{2} \mathrm{O}_{2}$ hemolysis was observed in severe iron deficiency anemia in children. As reported by the authors previously, abnormally elevated $\mathrm{H}_{2} \mathrm{O}_{2}$ hemolysis values were also observed in 11 out of 40 cases of iron deficiency anemia(7).

These facts suggest that serum vitamin $\mathrm{E}$ and serum lipid components such as cholesterol, triglyceride, and beta-lipoprotein are closely related to the fragility of red blood cells in iron deficiency anemia. On the other hand, it is well known that fragile red blood cells play an important role as a cause of splenomegaly. Accordingly, it seems possible that low serum vitamin E level and abnormalities in serum lipid components, as those mentioned above, may play some role in splenomegaly observed in cases of iron deficiency anemia.

The real cause of the abnormalities in serum lipid levels observed in cases of iron deficiency anemia is not known. However, several reports have been made on iron deficiency anemia caused by idiopathic steatorrhea (20-22). In addition, it has been reported that there is a reduction of lipase activity in duodenal secretions(23) and impairment of intestinal absorption of vitamin A in cases of severe protein calorie malnutrition(24). Several investigators have also reported the lack of iron and vitamin $\mathrm{E}$ besides the lack of other hematopoietic substances such as protein, folic acids, and vitamin $B_{12}$ in this disease(25-29). These reports seemed to indicate possible impairment of intestinal absorption of lipids and fat soluble vitamins in cases of iron deficiency anemia. There were, however, no subjects in this study who showed any clinical signs of idiopathic steatorrhea nor was there evidence available to support such speculation in cases of iron deficiency anemia in adolescence.

As for the cause of low serum vitamin E level observed in some cases of iron deficiency anemia, the correlation between serum vitamin $\mathrm{E}$ levels and serum betalipoprotein levels is thought to be important. Vitamin $\mathrm{E}$ transiently present in chylomicrons following meals and in the serum is associated with beta-lipoprotein $(30)$. It has been reported that vitamin $\mathrm{E}$ is virtually absent from the serum of patients with abetalipoproteinemia(31). KATER and UNTERECKER(32) indicated that a direct correlation was found between concentration of vitamin $\mathrm{E}$ and beta-lipoprotein in serum in patients with severe liver cirrhosis and fulminant hepatitis who showed a decrease in serum vitamin E levels. This fact may suggest that low serum beta-lipoprotein levels play an important part as the cause of decreased serum vitamin $\mathrm{E}$ level in iron deficiency anemia. In addition to low serum beta-lipoprotein levels, insufficient dietary vitamin $E$ intake in Japanese(33) and, as previously reported(34), an increased vitamin $\mathrm{E}$ demand in the body due 
to rapid iron turnover in the iron deficient state are also considered to be possible factors.

\section{REFERENCES}

1) JАCOB, H. S. and Lux, S. E., Blood, 32, 549 (1968).

2) Binder, H. J., Herting, D. C., Hurst, V., Finch, S. S., and Spiro, H. M., New Eng. J. Med., 273, 1289 (1965).

3) Gordon, H. H., Nitowsky, H. M., and Cornblath, M., Am. J. Dis. Child., 90, 669 (1955).

4) Nitowsky, H. M., Cornblath, M., and Gordon, H. H., Am. J. Dis. Child., 92, 164 (1956).

5) Mackenzie, J. B., Pediatrics, 13, 346 (1953).

6) Melhorn, D. K., and Gross, S., J. Lab. Clin. Med., 74, 789 (1969).

7) FüII, T., Shimizu, H., and EdA, I., J. Vitaminol., 18, 84 (1972).

8) ERBen, F., Ztschr. Klin. Med., 47, 302 (1902).

9) Refkind, B. and Gale, M., Am. Heart. J., 76, 849 (1968).

10) FuנII, T., Jap. J. Clin. Hemat., 11, 365 (1970).

11) FuJI, T., Acta Haem. Jap., 33, 197 (1970).

12) Fuji, T., Matsuki, Y., and Hasegawa, M., Keio J. Med., 17, 193 (1968).

13) Reed, C. F., Swischer, S. N., Marinetti, G. K., Eden, E. G., J. Lab. Clin. Med., 56, 281 (1960).

14) DE GIER, J. and van DeEn, L. L. M., Biochim. Biophys. Acta, 49, 286 (1961).

15) Reed, C. F., Murphy, M., and Roberts, G., J. Clin. Invest., 47, 749 (1968).

16) Weed, R. I., and Reed, C. F., Am. J. Med., 41, 681 (1966).

17) Donabedian, R. K., and Karmen, A., J. Clin. Invest., 46, 1017 (1967).

18) Silber, R., Winter, R., and KAYden, H. J., J. Clin. Invest., 48, 2089 (1969).

19) Dodge, J. T., Cohen, G., Kayden, H. J., and Phillips, G. B., J. Clin. Invest., 47, 357 (1967).

20) Hawkins, C. F., Peeney, A. L. P., and Cooke, W. T., Lancet, 2,387 (1950).

21) Estren, S., J. Mt. Sinai Hosp., 24, 304 (1957).

22) BADEnoch, J. and CAllender, S. T., Blood, 9, 123 (1954).

23) Thompson, M. D. and Trowell, H. C., Lancet, 1, 1031 (1952).

24) Arroyave, G., Viteri, F., Behar, M., and Scrimshaw, N. S., Am. J. Clin. Nutr., 7, 185 (1959).

25) Majaj, A. S., Dinning, J. S., Azzam, S. A., and Darby, W. J., Am. J. Clin. Nutr., 12, 374 (1963).

26) Majaj, A. S., Am. J. Clin. Nutr., 18, 362 (1966).

27) Whitaker, J. A., Fort, E. G., Serene, V., and Dinning, J. S., Am. J. Clin. Nutr., 20, 783 (1967).

28) Sanstead, H. H., Gabr, M. K., Azzam, S., Shuky, A. S., Weiler, R. J., El Din, O. M., El Hifney, A. E., and Darby, W. J., Am. J. Clin. Nutr., 17, 27 (1965),

29) Asfour, R. Y. and Firzli, S., Am. J. Clin. Nutr., 17, 158 (1965).

30) Fredrickson, D. S., Levy, R. I., and Lees, R. S., New Eng. J. Med., 276, 34 (1967).

31) Kayden, H. J., Silber, R., and Kossman, C. E., Trans. Assoc. Am. Physicians, 78, 334 (1965).

32) Kater, R. M. H. and Unterecker, W. J., Kim, C. Y., Davidson, C. S., Am. J. Clin. Nutr., 23, 913 (1970).

33) Ikehata, H., Tanaka, H., and Kamishima, C., Vitamins (Japan), 38, 253 (1968).

34) Fujir, T., Matsuki, Y., and Hasegawa, M., Keio J. Med., 17, 207 (1968). 